\title{
Evidence for a Big Brother Effect in Survey-Based Fear of Crime Research
}

\author{
Jessica Ashbourne*
}

\author{
University of Waterloo, 200 University Avenue West, LHN 3703, Waterloo, Ontario, N2L 3G1, Canada
}

\begin{abstract}
The objective of this study was to determine whether sibling sex and birth order have any influence on individuals' reported fear of crime levels. Based on literature relating to gender, socialization, vicarious fear for spouses and children, and sibling influence, three hypotheses were formed. It was expected that a) having siblings would be protective against fear, $b$ ) male fear of crime would increase with the number of younger sisters and c) female fear of crime would decrease with the number of older brothers. A total of 83 McMaster University undergraduate students completed a survey that included demographic questions and a fear of crime index. Results indicated the existence of a "big brother effect", whereby females with older brothers exhibited less fear of crime than other females. There was no statistically significant difference in fear of crime among those with and without siblings and no sex-specific sibling effects on fear of crime in males. Explanations of this result focused on female vulnerability, socialization and the particular influence of older brothers on their sisters' behaviour and characteristics. This study highlights the influence of siblings on fear of crime and provides impetus for future research.
\end{abstract}

Keywords: Fear of crime, sibling effect, big brother effect.

Fear of crime can have a serious impact on individuals' daily lives. Those who exhibit this fear can be considered indirect victims of crime (Warr 2000); if people are worried about being victimized, they will alter their behaviour accordingly. For example, May, Rader and Goodrum (2010:166) found that those who were more afraid of crime were significantly more likely to engage in avoidance behaviours, or to refrain from "doing things [they liked] to do." Fear can also have detrimental effects on social order by engendering distrust among individuals (Jackson 2006). Clement and Kleiman (1977:521) promoted changing public fear levels, stating "regardless of the extent to which the widespread fear of crime is unwarranted or irrational, the fact remains that it exists and demands alleviation."

While some suggest that unprovoked fear levels should be reduced (Clement and Kleiman 1977; Moore and Trojanowicz 1988; Renauer 2007), it is important to acknowledge the adaptive value of fear. Being less afraid than one should be could result in injury or death due to a lack of caution. In this sense, fear serves as a means of protection. However, unnecessarily high or irrational levels of crime-related fear may have very negative personal and social effects. Moore and Trojanowicz (1988) proposed that a shift in policing strategies could be useful in reducing public fear levels. Furthermore, a study conducted by Renauer (2007) indicated that neighbourhood social cohesion, police effectiveness and government responsiveness could

*Address correspondence to this author at the University of Waterloo, 200 University Avenue West, LHN 3703, Waterloo, Ontario, N2L 3G1, Canada; Tel: 1-519-888-4567 ext. 35879; Fax: 1:519-888-4362;

E-mail: jashbourne@uwaterloo.ca lead to fear reduction. Research into factors that might influence individual variation in fear of crime can help target such fear reduction strategies.

Scholars in the field of fear of crime research often strive to understand why certain groups of individuals are more fearful than others. It is well documented that females exhibit fear levels that exceed those of males (Brownlow 2005; McCrea, Shyy, Western and Stimson 2005; Miller 2008; Jackson 2009; May et al. 2010). Much of the research in this field has endeavoured to identify possible reasons for this sex-difference in fear of crime, especially considering the fact that males are more often the victims of many types of crime (Vaillancourt 2010). Investigations of sex-differences in fear of crime have been extended to include the association between spousal and parent-child relations and fear of crime; however, there remains a gap in the literature on the topic of sibling relations and fear of crime (Warr 1992; Warr and Ellison 2000; Mesch 2000; Snedker 2006; Rader 2010). This study builds on theory and literature relating to gender socialization and fear, familial relationships and fear, and general sibling influence to inform hypotheses suggesting a sex-dependent relationship between siblings and fear of crime.

\section{Gender Socialization and Fear}

Numerous studies have demonstrated that females exhibit more fear than males (McCrea et al. 2005; Miller 2008; Jackson 2009; May, Rader \& Goodrum 2010). Among urban residents in Canada, 3.6 percent more women than men reported feeling unsafe walking alone after dark (Fitzgerald 2008). This sex difference 
exists despite the facts that a) men are more often physically assaulted in public places outside their homes than women and b) overall rates of violent victimization for Canadian males and females are comparable (Vaillancourt 2010).

A predominant theory explaining the apparent inconsistency between fear of crime and crime victimization is known as "the vulnerability hypothesis" (McCrea et al. 2005:9). Essentially, it proposes that females feel more vulnerable than males because they are less able to physically defend themselves and feel less in control over crime occurrence; therefore, they are "more sensitive to the consequences of victimization" (Jackson 2009:368). Qualitative research conducted by Hollander (2001) found that participants identified women as being particularly vulnerable to violence, whereas men were viewed as relatively invulnerable. Furthermore, many participants voiced opinions that men may serve to protect women; however, women were never proposed to be protectors of men. De Groof (2008) suggested that feelings of vulnerability in women may result from socialization by parents during childhood.

A related hypothesis attempting to explain the sex difference in fear levels proposes that males are less likely to admit fear due to worry that their masculinity may become compromised (Brownlow 2005). This hypothesis is consistent with the theory of gendered fear of crime socialization developed by Rader and Haynes (2011), which suggests that sex differences in fear of crime can be explained by gender socialization or the "process whereby individuals learn what it means to be men or women" (Rader and Haynes 2011:298). In a study assessing socially desirable responding and fear of crime, Sutton and Farrall (2005) found that male participants reported levels of fear that were inversely related to scores on a lie scale. This evidence provides support for the idea that men may feel pressure to supress the expression of fear. Both hypotheses of gender-based fear of crime discussed above suggest that socialization by family members during childhood is an important factor influencing the differential expression of fear of crime among males and females.

\section{Familial Relationships and Fear of Crime}

Through socialization, families may influence how children experience and express emotion (Bronstein et al. 1996), which may extend to fear of crime. The link between fear of crime and relationships within the nuclear family has been examined in spousal and parent-child relationships (Warr and Ellison 2000; Snedker 2006; Rader 2010). Studies involving familial relationships and fear of crime have focused on vicarious or altruistic fear as opposed to personal fear of crime (Warr and Ellison 2000; Snedker 2006; Rader 2010). Vicarious or altruistic fear refers to one's fear for others while personal fear indicates a more self-centred fear of becoming a victim of crime. Warr and Ellison (2000) found that the two types of fear, though conceptually distinct, were positively correlated (Warr and Ellison 2000), suggesting that the two types of fear may be related.

\section{Fear for Spouses}

Warr (1992) conducted the first study examining altruistic fear of crime in households and discovered approximately three times more men than women expressed concern for their significant other $(33 \%$ versus $10 \%$ ). The heightened level of fear for wives compared to husbands is consistent with the idea that women are more vulnerable and in need of more protection than men (Hollander 2001). Warr's (1992) study focused solely on altruistic fear and did not provide a comparison between personal fear and fear for others.

Warr and Ellison (2000) expanded on Warr's (1992) initial work and again discovered that there were significant differences in vicarious fear between married men and married women. Specifically, married men were more likely to fear for their wives than vice versa. In addition, the investigators found that the level of individuals' vicarious fear was positively correlated with the intensity of their personal fear.

Subsequent qualitative work further illuminated important sex differences in vicarious fear for significant others. For example, Snedker (2006) found that men who were fathers or spouses felt a responsibility to protect others. Fear for wives appeared to stem from recognition of certain risks associated with being a woman (i.e., sexual assault). Though women feared for other groups of individuals, they did not express fear for their husbands.

Rader (2010), through a series of interviews, investigated important changes in personal and vicarious fear of crime that occurred as a result of becoming a husband or a wife. Men noted that, after they were married, they became more aware of crime and more concerned with both their own safety and that of their wives. One participant admitted feeling like 
he had an "obligation to try and live as long as possible" (Rader 2010:45), implying that his personal caution stemmed from a feeling of responsibility for his wife's safety. Conversely, women reported that they felt safer in the company of their spouses and did not worry about their husbands' safety. One participant felt that telling her husband to be careful would compromise his sense of masculinity. Clearly, perceived gender roles played a large role in the rationalization of personal fear levels in these individuals.

\section{Fear for Children}

Many of the studies conducted to examine fear for spouses also investigated fear for children. Warr (1992) found that children engendered more concern than any other group of individuals. Whereas men were more likely than women to fear for their spouses, women were more likely than men to fear for their children (38\% versus 11\%) (Warr 1992). Further, Mesch (2000) found that vicarious fear for children among women was even greater than their own personal fear.

Warr and Ellison (2000) similarly found that vicarious fear for children was more common than fear for significant others. Not only did the investigators find a sex difference in the sources of fear (mothers and fathers), but they also found a sex difference in the objects of fear (daughters and sons). Daughters were the object of fear among parents more often and for a longer duration compared to sons. Furthermore, a higher level of fear for children was associated with a higher level of personal fear. The fear for children and, more specifically, the fear for daughters exhibited by parents is in line with a vulnerability hypothesis of fear; young women are viewed as vulnerable to criminal victimization, thus they generate concern among others.

\section{Sibling Influence}

It has been proposed that competition between siblings over resources, such as parental affection, can cause children to develop birth-order-dependent behaviour patterns and personality traits (Sulloway 1996). There is some controversy over whether the results of birth-order research are truly grounded in reality (Ernst and Angst 1983). However, socializationbased hypotheses regarding the differential expression of fear among males and females, as well as evidence for the differential expression of vicarious fear for family members, suggest that family is an important influencing factor in the gendered experience of fear. Since fear of crime has not been investigated through the lens of sibling influence, literature involving siblings, personality and behaviour more generally is reviewed here.

Simply having siblings may directly or indirectly affect the development of certain behaviour patterns (Brody 2004). For example, Kitzmann, Cohen and Lockwood (2002) found that peers described onlyborns (individuals without siblings) as passive and as more often victimized than other children, indicating that only-borns may be disadvantaged in terms of the development of conflict management skills. Positive sibling relations may provide additional psychological benefits. Jenkins and Smith (1990) found that good sibling relations were protective against psychiatric symptomology in children living with marital conflict. Similarly, Gass, Jenkins and Dunn (2007) found that sibling affection served as a protective factor against internalizing symptomology following a stressful life event.

Sibling age and sibling sex may interact with general sibling influence to produce more specific effects. For example, Sandler (1980) found that having older siblings particularly reduced adverse consequences of stress in children. This finding supports Sutton-Smith and Rosenberg's (1970) assertion that later-born children are most influenced by their older siblings. Sutton-Smith and Rosenberg (1970:25) also suggest that "females are more affected by males than vice versa." Kornreich, Hearn, Rodriguez and O'Sullivan (2003) combined the concepts of older sibling influence and male sibling influence, in their conclusion that older brothers may protect their younger sisters against involvement with older men. The importance of this cross-sex sibling relationship is echoed in the work of Stoneman and Brody (1986), which found that girls with older brothers showed less evidence of gender stereotyping and participated in more stereotypically male activities than other girls.

\section{Objective and Hypotheses}

The aim of this study is to investigate an aspect of fear of crime that has, as of yet, been overlooked: the association between fear of crime and sibling relationships. The present study applies to fear of crime the idea that an individual's siblings can affect his or her personality, and behaviour (Sutton-Smith and Rosenburg 1970). The concept of fear among siblings has not been previously investigated; therefore, the hypotheses of this study are grounded in theories and evidence relating to gender, socialization, vicarious fear for spouses and children, and sibling influence. 
Literature on sibling influence indicates a general protective effect of having siblings in terms of adjustment and psychological wellbeing. Thus, it is expected that having siblings will be protective against fear of crime. In other words, it is expected that onlyborns will be more afraid of crime than persons who have at least one sibling.

Sex-specific interactions have dominated the results of fear of crime research; therefore, it is expected that females in general will exhibit more fear than males. Socialization theory proposes that family members may influence the development of gendered fear of crime during childhood. Furthermore, people are more likely to fear for women than for men, and vicarious fear is greater for groups of individuals who are more vulnerable (particularly young people and women) (Warr 1992; Warr and Ellison 2000; Mesch 2000; Snedker 2006; Rader 2010). Based on previously documented correlations between vicarious and personal fear, it is expected that male fear of crime will increase with the number of younger female siblings (Warr and Ellison, 2000).

The fear exhibited by the more vulnerable factions of the population (i.e., young women) can be curbed by the presence of less vulnerable protective figures, as was seen in qualitative work involving men and women who had recently become married (Rader 2010). Along with evidence signifying the importance of the older brother-younger sister relationship (Sutton-Smith and Rosenberg 1970; Kornreich, Hearn, Rodriguez and O'Sullivan 2003; Stoneman and Brody 1986), the notion of protection provided by less vulnerable individuals served as a basis for the hypothesis that female fear will decrease with the number of older male siblings.

\section{METHODS}

\section{Participants and Procedure}

From January to March of 2011, a survey of McMaster University undergraduate students was conducted in Hamilton, Ontario. During the 2010-2011 school year, there were 24,520 students enrolled at the undergraduate level at McMaster University, and approximately $54 \%$ of the student population was female (McMaster University Office of Institutional Research and Analysis [MUOIRA] 2011). A total of 83 students participated in this study, and $62.7 \%$ of the study population was female. The discrepancy between the sex distribution in the university population and the study population can be partially explained by the fact that most participants were recruited from an undergraduate psychology course. Many of the individuals who enrol in psychology courses are students within the Department of Social Sciences, and $65.6 \%$ of the Department of Social Sciences in 20102011 was female (MUOIRA 2011). Participants' ages ranged from 17 to 41 , with a mean age of 19.7 .

Since sibling status is central to this study, the distribution of only-born participants, first-born participants, middle-born participants and last-born participants is displayed in Table 1. Almost half of the study participants were first-born $(45.8 \%)$. The high percentage of first-borns in the study population is not entirely unexpected, as it is consistent with Schachter's (1963) claim that first-borns are overrepresented in college populations.

Table 1: Demographic Characteristics of the Study Population

\begin{tabular}{|c|c|c|}
\hline Characteristic & Number & Percent \\
\hline \multicolumn{3}{|l|}{ Sex } \\
\hline Male & 31 & 37.3 \\
\hline Female & 52 & 62.7 \\
\hline Total & 83 & 100 \\
\hline \multicolumn{3}{|l|}{ Age } \\
\hline $17-19$ & 65 & 78.3 \\
\hline $20-22$ & 15 & 18.1 \\
\hline $25+$ & 3 & 3.6 \\
\hline Total & 83 & 100 \\
\hline \multicolumn{3}{|l|}{ Birth Order } \\
\hline Only-born & 10 & 12 \\
\hline First-born & 38 & 45.8 \\
\hline Middle-born & 13 & 15.7 \\
\hline Last-born & 22 & 26.5 \\
\hline Total & 83 & 100 \\
\hline \multicolumn{3}{|l|}{ \# of Siblings } \\
\hline $0-1$ & 53 & 63.9 \\
\hline $2-3$ & 25 & 30.1 \\
\hline $4-6$ & 5 & 6 \\
\hline Total & 83 & 100 \\
\hline
\end{tabular}

Participants were obtained through two recruitment strategies. Seventy-seven first year psychology students were recruited through the McMaster Experimetrix website (https://experimetrix2.com/mac/), which allows researchers to advertise experiments and schedule student participants. Students received a one-hour research participation credit for their Psychology $1 \mathrm{XX} 3$ course. An additional six volunteers 
were recruited by advertising to the general McMaster population via social media platforms. All participants were required to read and sign a consent form. Prior to answering the questions, participants were required to read a series of definitions adapted from the Statistics Canada website, including definitions for homicide, violent crime and sexual assault (Vaillancourt 2010). Following survey completion, participants were given a debriefing form.

\section{Survey Apparatus and Measures}

The survey consisted of five sections: a fear of crime index, factual questions about crime in Canada, a punitive attitude scale, personality scales (sensation seeking and self-efficacy) and demographic questions. Since the data was collected with the intention of being used by multiple researchers assessing different research questions, only the specific sections discussed in this paper (fear of crime and demographics) will be elaborated upon.

\section{Fear of Crime}

The definition and appropriate measurement of fear of crime are a matter of debate among researchers in the field (Ferraro and Grange 2007). Gray, Jackson and Farrall (2008) suggest that crime can elicit different types of fear, including fear as a relatively stable personality trait and fear as a short-term affective state. It is important to acknowledge which type of fear is actually being assessed in fear of crime surveys. Many surveys base fear measurements on a single question about whether respondents are afraid walking alone at night. This measurement has been criticized for not mentioning crime explicitly and, as a result, indicating a more general state of fear (Ferraro and Grange 2007). For this reason, the present study used a less general fear of crime index, which assessed fear on a crimespecific basis (May et al. 2010). Even when crimespecific questions are asked, it is likely that respondents conflate the related states of fear, anxiety, dissatisfaction, and mild concern in responding to questions about fear (Gray et al. 2008). This more global fear measurement may lead to overestimation of fear of crime (McCrea et al. 2005). Presently, a survey technique that overcomes all of these barriers has not been discovered. However, using surveys that include crime-specific questions ensures that fear measurements relate directly to fear of crime as opposed to general fear of being alone or in the dark.

The fear of crime index used in this study was developed by May and colleagues (2010) in conjunction with the Kentucky Justice Cabinet and Criminal Justice Council representatives. Fear of crime was measured by asking participants to indicate their level of agreement with a series of six statements. Responses to each question were scored on a fivepoint Likert-type scale (strongly agree $=5$ and strongly disagree $=1$ ). Potential scores on the index ranged from 6 (least fearful) to 30 (most fearful). May and colleagues (2010) found that the internal reliability of the survey was high (Cronbach's $\alpha=.863$ ).

\section{Demographics}

The participants were asked to provide their age, sex, number of older, younger, male and female siblings. An additional five questions about relationship status, citizenship, place of birth, actual height and perceived height were included in the survey but were used only for a colleague's data analysis.

\section{Data Analysis}

Data were analysed using SPSS v. 20 (IBM Corp. 2011) to test the hypotheses that a) having siblings is protective against fear, b) in males, fear of crime will increase with the number of younger sisters, and c) in females, fear of crime will decrease with the number of older brothers. An independent samples t-test was used to determine whether females had higher levels of fear than males. Further t-test comparisons and correlation analyses were used to determine main effects of siblings on fear of crime. Finally, a regression analysis was conducted in females to determine the effect of older brothers on fear of crime while holding other important variables constant.

\section{RESULTS}

\section{Sex Effect and General Sibling Effects}

An independent samples t-test was conducted to determine whether having siblings was associated with a lower level of fear of crime. The results presented in Table 2 indicate there was a trend towards a heightened level of fear of crime in only children; however, the results were not significant $\left(t_{50}=-1.539, p\right.$ $=.128$ ).

Subsequently, a correlation analysis was conducted to determine whether the number of siblings, rather than the mere presence of siblings, was associated with higher fear of crime scores. As shown in Table 3, there was a significant, slightly negative correlation between number of siblings and fear of crime, i.e., as 
Table 2: T-Test Results Comparing Mean FOC among Children With and Without Siblings

\begin{tabular}{|c|c|c|c|c|c|c|c|}
\hline & Only Child & $\mathbf{N}$ & Mean & Std. Deviation & t-calculated & df & $\mathbf{p}$ \\
\hline \hline \multirow{2}{*}{$\begin{array}{c}\text { Fear of crime } \\
\text { score }\end{array}$} & No & 73 & 14.67 & 5.888 & -1.539 & 81 & 0.128 \\
\cline { 2 - 8 } & Yes & 10 & 17.70 & 5.417 & & & \\
\hline
\end{tabular}

the number of siblings increased, there was a small decrease in fear of crime.

Table 3: Correlation between Fear of Crime and Number of Siblings

\begin{tabular}{|c|c|c|}
\hline \multicolumn{2}{|c|}{} & Fear of crime score \\
\hline \hline \multirow{3}{*}{ \# of siblings } & Pearson Correlation & $-.275^{*}$ \\
\cline { 2 - 3 } & Sig. (2-tailed) & .012 \\
\cline { 2 - 3 } & $\mathrm{N}$ & 83 \\
\hline
\end{tabular}

\section{Sex-Specific Sibling Effects}

As expected, females exceeded males in their total fear of crime score $\left(\mathrm{t}_{81}=-4.451, \mathrm{p}<.001\right)$. Two correlation analyses, one for each sex, were conducted to determine if fear of crime was correlated with the number of participants' older brothers, older sisters, younger brothers or younger sisters. Table 4 shows that, in males, there were no significant correlations between fear of crime and the number of siblings in any of the sibling categories.
In females, a significant negative correlation between fear of crime score and number of older brothers was found (Table 5, $r=-.385, p=.005$ ). No other significant correlations were found for women. An independent samples t-test was conducted to test the difference in mean fear of crime scores between females with and without older brothers. Fear of crime was significantly lower in females with older brothers than in females with no older brothers (Table $6, t_{50}=$ $3.479, p=.001)$. Mean fear of crime in girls without older brothers was 18.59 whereas mean fear of crime in girls with older brothers was 13.20 , a mean difference of approximately 5.4 points on the fear of crime index.

Finally, Table 7 displays the results of a regression analysis conducted in females to determine the effect of the number of older brothers on fear of crime while holding other variables constant (dependent variable $=$ fear of crime; independent variables = number of older brothers, number of younger brothers, number of older sisters, age, number of siblings). The variable for

Table 4: Correlations between Number of Siblings within Specific Subgroups and Fear of Crime Scores in Males

\begin{tabular}{|c|c|c|c|c|c|c|}
\hline & & Older brothers & $\begin{array}{l}\text { Younger } \\
\text { brothers }\end{array}$ & Older sisters & $\begin{array}{l}\text { Younger } \\
\text { sisters }\end{array}$ & Fear of crime score \\
\hline \multirow[t]{3}{*}{ Older brothers } & Pearson Correlation & 1 & $-.356^{*}$ & .238 & -.208 & .177 \\
\hline & Sig. (2-tailed) & & .049 & .198 & .261 & .341 \\
\hline & $\mathrm{N}$ & 31 & 31 & 31 & 31 & 31 \\
\hline \multirow[t]{2}{*}{ Younger brothers } & Pearson Correlation & $-.356^{*}$ & 1 & -.269 & -.007 & -.206 \\
\hline & $\mathrm{N}$ & 31 & 31 & 31 & 31 & 31 \\
\hline \multirow[t]{3}{*}{ Older sisters } & Pearson Correlation & .238 & -.269 & 1 & -.238 & .300 \\
\hline & Sig. (2-tailed) & .198 & .143 & & .198 & .101 \\
\hline & $\mathrm{N}$ & 31 & 31 & 31 & 31 & 31 \\
\hline Younger sisters & $\mathrm{N}$ & 31 & 31 & 31 & 31 & 31 \\
\hline \multirow{3}{*}{$\begin{array}{l}\text { Fear of crime } \\
\text { score }\end{array}$} & Pearson Correlation & .177 & -.206 & .300 & -.213 & 1 \\
\hline & Sig. (2-tailed) & .341 & .267 & .101 & .250 & \\
\hline & $\mathrm{N}$ & 31 & 31 & 31 & 31 & 31 \\
\hline
\end{tabular}

${ }^{*}$ Correlation is significant at the 0.05 level (2-tailed). 
Table 5: Correlations between Number of Siblings within Specific Subgroups and Fear of Crime Scores in Females

\begin{tabular}{|c|c|c|c|c|c|c|}
\hline & & Older brothers & $\begin{array}{l}\text { Younger } \\
\text { brothers }\end{array}$ & Older Sisters & $\begin{array}{l}\text { Younger } \\
\text { sisters }\end{array}$ & Fear of crime score \\
\hline \multirow[t]{3}{*}{ Older brothers } & Pearson Correlation & 1 & .060 & -.023 & -.040 & $-.385^{* *}$ \\
\hline & Sig. (2-tailed) & & .673 & .874 & .780 & .005 \\
\hline & $\mathrm{N}$ & 52 & 52 & 52 & 52 & 52 \\
\hline \multirow[t]{3}{*}{ Younger brothers } & Pearson Correlation & .060 & 1 & -.064 & .121 & -.012 \\
\hline & Sig. (2-tailed) & .673 & & .653 & .392 & .932 \\
\hline & $\mathrm{N}$ & 52 & 52 & 52 & 52 & 52 \\
\hline \multirow[t]{3}{*}{ Older Sisters } & Pearson Correlation & -.023 & -.064 & 1 & -.145 & -.183 \\
\hline & Sig. (2-tailed) & .874 & .653 & & .306 & .194 \\
\hline & $\mathrm{N}$ & 52 & 52 & 52 & 52 & 52 \\
\hline \multirow[t]{3}{*}{ Younger sisters } & Pearson Correlation & -.040 & .121 & -.145 & 1 & .071 \\
\hline & Sig. (2-tailed) & .780 & .392 & .306 & & .618 \\
\hline & $\mathrm{N}$ & 52 & 52 & 52 & 52 & 52 \\
\hline \multirow{3}{*}{$\begin{array}{l}\text { Fear of crime } \\
\text { score }\end{array}$} & Pearson Correlation & $-.385^{* *}$ & -.012 & -.183 & .071 & 1 \\
\hline & Sig. (2-tailed) & .005 & .932 & .194 & .618 & \\
\hline & $\mathrm{N}$ & 52 & 52 & 52 & 52 & 52 \\
\hline
\end{tabular}

${ }^{* *}$ Correlation is significant at the 0.01 level (2-tailed).

Table 6: T-Test Results Comparing Mean Fear of Crime Scores among Females With and Without Older Brothers

\begin{tabular}{|c|c|c|c|c|c|c|c|}
\hline & Older Brother & $\mathbf{N}$ & Mean & Std. Deviation & t-calculated & df & $\mathbf{p}$ \\
\hline \hline \multirow{2}{*}{$\begin{array}{c}\text { Fear of crime } \\
\text { score }\end{array}$} & No & 37 & 18.59 & 5.161 & 3.479 & 50 & 0.001 \\
\cline { 2 - 8 } & Yes & 15 & 13.20 & 4.814 & & & \\
\hline
\end{tabular}

Table 7: Regression Analysis Indicating a Relationship between Fear of Crime and Number of Older Brothers While Holding other Variables Constant

\begin{tabular}{|c|c|c|c|c|c|c|}
\hline & \multirow[b]{2}{*}{ Model } & \multicolumn{2}{|c|}{ Unstandardized Coefficients } & \multirow{2}{*}{$\begin{array}{c}\begin{array}{c}\text { Standardized } \\
\text { Coefficients }\end{array} \\
\text { Beta }\end{array}$} & \multirow[b]{2}{*}{$\mathbf{t}$} & \multirow[b]{2}{*}{ Sig. } \\
\hline & & B & Std. Error & & & \\
\hline \multirow[t]{6}{*}{1} & (Constant) & 24.531 & 5.696 & & 4.307 & .000 \\
\hline & Older brothers & -4.989 & 1.790 & -.452 & -2.788 & .008 \\
\hline & Younger brothers & -.884 & 2.121 & -.071 & -.417 & .679 \\
\hline & Older Sisters & -3.102 & 1.834 & -.293 & -1.691 & .098 \\
\hline & Age & -.342 & .334 & -.197 & -1.024 & .311 \\
\hline & \# of Siblings & 1.198 & 1.385 & .237 & .865 & .392 \\
\hline
\end{tabular}

${ }^{a}$ Dependent Variable: Fear of crime score.

younger sisters was removed due to multicollinearity. Results indicate that, in females, fear of crime decreases by 5 points (out of a possible Fear of Crime Score of 36) when the number of older brothers increases by one, while holding the number of younger brothers, number of older sisters, age, and total number of siblings constant $(B=-4.989, p=.008)$.

\section{DISCUSSION}

\section{General Sibling Effects}

It was expected that having siblings would be protective against high levels of fear of crime. Although the results showed a trend towards higher levels of fear 
in study participants without siblings, the results were not significant. The lack of a significant result could be a product of the small sample size of the study. There were a total of 10 only children included in the study. Although there was a trend in the expected direction, further research with a larger sample size is necessary to clarify whether simply having siblings is protective against fear of crime.

That said, the lack of a significant difference in fear among only-born participants and participants with siblings is consistent with the results of meta-analyses conducted by Falbo and Polit (1986), which found that only-born children were not developmentally disadvantaged compared to other children. It was proposed that a very positive parent-child relationship might compensate for the lack of sibling support during childhood. Therefore, future research should include analyses of parent-child relationship quality in order to further examine the reasons for an absence of general sibling effects.

The results of this study also showed that fear of crime slightly decreased with an increase in the number of an individual's siblings. Previous research has focused on the relationship between sibship size (i.e., number of siblings) and intellectual development (Steelman 1985). An increase in number of siblings has generally been negatively associated with intellectual outcomes, and dilution in resources has been proposed as an explanation (Downey 2001). In the case of fear of crime, a larger sibship size was associated with a decrease in fear of crime. Research conducted by May, Vartanian and Virgo (2002) found that males whose parents supervised them were more afraid of crime than other males. De Groof (2008) also examined the impact of parents on fear of crime level and found a similar association between close parental supervision and fear of crime. These findings suggest that dilution of resources, and more specifically the resource of time, is actually protective against high levels of fear. The results of the present study indicate that more siblings might be associated with less supervision per child, which in turn might reduce fear of crime.

\section{Sex-Specific Sibling Effects}

Regarding sex-specific associations, it was expected that males with younger sisters would exhibit more fear than other males and that females with older brothers would exhibit less fear than other females. Only one significant sex-specific sibling effect was found: the big brother effect. Women with older brothers exhibited significantly less fear of crime than those without older brothers. Furthermore, there was a dose-response effect, wherein the number of older brothers was negatively correlated with fear of crime. These findings can be explained in multiple ways.

\section{Vulnerability and Socialization}

Females with older brothers may feel like their personal vulnerability is reduced by the presence of a less vulnerable older male figure in their lives. The importance of male presence in the reduction of fear was described in qualitative research conducted by Rader (2010). Participants reported feeling safer "living with a guy" and "just having a man around" (Rader 2010:50). Kornreich and colleagues (2003) illuminated the protective role of the older brother in a review of transcripts of focus groups assessing sexual socialization in adolescent girls. Participants described their brothers as serving a protective role by preventing or discouraging interactions with certain men. In this sense, brothers may protect their younger sisters from potentially harmful social encounters.

The roles of the vulnerable younger sister and the protective older brother may be the result of socialization during childhood; specifically, females are socialized to feel vulnerable whereas men are socialized to be invulnerable (De Groof 2008). The idea of differential socialization of vulnerability and fear among males and females is supported by evidence that adolescent women are rewarded for expressing fear and adolescent men are punished for expressing fear (Garside and Klimes-Dougan 2002). This explanation for the "big brother effect" reflects the vulnerability hypothesis (McCrea et al. 2005, Jackson 2009) and provides support for a theory of gendered fear of crime socialization (Rader and Haynes 2011).

Rader and Haynes (2011) applied the principles of Akers' Social Learning Theory to the idea of gendered fear of crime socialization. One important principle discussed by the authors was imitation, whereby gendered fear of crime behaviours may persist because "individuals 'imitate' what they have learned from others" (pg. 301). Although siblings were not explicitly cited as members of the "others" category, literature on sibling influence indicates that siblings do influence each other's characteristics and behaviour. For example, Stoneman and Brody (1986) compared cross-sex and same-sex siblings regarding activity choices and gender stereotypes and found that girls with older brothers engaged in more male activities and 
showed less gender stereotyping than other girls. Volcom (2003) investigated whether siblings or sibling activities were correlated with childhood "tomboyism," which can be defined as female preferences for traditionally male activities. She found that there was no overall correlation between having an older brother and being a tomboy, but tomboyism was significantly related to certain activities that girls' older brothers engaged in. These results suggest that low fear levels in girls with older brothers may be a result of a decrease in gender stereotyping due to presence of a male role model.

Rader and Haynes (2011:299) proposed that "gendered fear of crime socialization rests on a continuum ranging from low fear/masculinity to high fear/femininity." The authors asserted that individuals may fall anywhere within the continuum. The influence of older brothers on the fear of their younger sisters might alter their place on the fear continuum, moving them closer toward the more masculine end of the spectrum.

\section{Parental Supervision}

May, Vartanian and Virgo (2002) found that males who had parents that actively supervised them more often were more afraid of crime. De Groof (2008) extended this finding to all adolescents. It is possible that parental supervision of girls with older brothers is decreased due to the presence of an additional protective figure. Price (2008) found that first-born children spent more time with their parents than laterborn children. Furthermore, in families consisting of an older male child and a younger female child, there was a greater difference between first- and second- born children regarding time spent with their parents than other sibship compositions.

\section{The Importance of older Brothers}

This study provides evidence for only one sibling effect: a significant effect of older brothers on female fear of crime. The particular significance of the older brother-younger sister relationship was also identified in a study conducted by Branje, van Lieshout, van Aken and Haselager (2004), which found that aggressive behaviour was significantly lower in girls with older brothers than in other girls. Similar to the present study, Branje and colleagues (2004) did not find any other significant sibling effects. The strength of the older brother-younger sister relationship is supported by Sutton-Smith and Rosenberg's (1970) conclusions that a) females are more susceptible to sibling influence than males and $b$ ) later-borns are more affected by older siblings than vice versa. These sex- and birth order-related differences in predisposition to sibling influence may explain the lack of any significant effects in males.

The hypothesis that male fear would decrease with the number of younger sisters was based on vicarious fear research that indicated that females (i.e., wives and daughters) engendered the greatest amount of fear among men. Although studies have found that altruistic fear and personal fear are related, fear for younger sisters may not be strong enough to influence males' personal fear of crime (Warr and Ellison 2000). Rader (2010) found that personal caution exhibited by males was influenced by feelings of responsibility for the safety of others. Brothers may not feel the same degree of responsibility as fathers or husbands, thus their fear for others may not be as strong (Rader 2010).

\section{Study Limitations}

There are some clear limitations to the study including the fact that the sample was relatively homogenous. A convenient sample of undergraduate students is not ideal, as it affects the generalizability of the results. That being said, this study provides initial insight into the potential effects of siblings on fear of crime.

The strengths of this study are greatly attributed to its novelty. The hypotheses tested here have not been examined in the work of previous researchers, despite that fact that Warr (1992) explicitly identified a research gap relating to fear of crime and siblings. Furthermore, the results provide an impetus for further similar research, which is valuable in its own right. Future research might include an examination of vicarious fear for siblings and correlations with personal fear. Although this study used literature on vicarious fear to inform hypotheses for sex-specific sibling effects on fear of crime, the study survey did not include questions about fear for siblings. These questions could help further explain the influence of siblings on the experience of fear. Furthermore, qualitative research could be useful for clarifying and expanding the understanding of a "big brother effect" in the fear of crime of women.

\section{IMPLICATIONS AND GENERAL CONCLUSIONS}

Some researchers and policy makers insist that fear of crime is an issue that requires alleviation (Clement 
and Kleinman 1977; Moore and Trojanowicz 1988; Renauer 2007). Before fear reduction can be demanded, one must question the distinction between a reasonable versus an unwarranted amount of fear. If programs are implemented to reduce fear of crime levels, there may be a risk that the resulting decline in fear may be too extreme. Consider a hypothetical society where no one is afraid of crime. With inhibitions, which may be moderated by fear, at an extreme low, it is possible that people will be reckless with regard to their personal safety. Though this example presents an unrealistic extreme, it illustrates the potential importance of some level of fear. Further research is needed to determine how reasonable current fear of crime levels are, and whether they truly necessitate fear reduction policies and programs.

If fear reduction was identified as a goal, this study's findings could provide insight into what kind of reduction programs might be effective in reducing fear of crime in women. If the "big brother effect" is taken as support for the vulnerability hypothesis, then perhaps the presence of public figures that are similarly perceived as less vulnerable may be effective.

Policing strategies have been offered as potentially effective measures of fear reduction (Moore and Trojanowicz 1988; Renauer 2007). With respect to the present study's sample of undergraduate students, increasing visibility of police or security on university campuses could lead to a reduction of fear among students. Though some studies have investigated the influence of police visibility on crime-related fear, evidence for a relationship between police presence and fear of crime is inconclusive. Salmi, Gronroos and Keskinen (2004) found that those who observed police patrolling on foot had reduced fear of property crime (in adults) and crimes against persons (in teenagers). Conversely, Ferguson and Mindel (2007) did not find a significant association between police presence and fear of crime. Further research is required to determine the nature of the relationship between police visibility, perceived vulnerability, and crime-related fear.

Alternatively, the impact of having a big brother on fear of crime may develop over one's lifetime and is, therefore, dissimilar to the influence of police visibility on the degree of fear. Studying the consistency of the "big brother effect" across different age groups would be useful in determining whether women with big brothers are always less afraid of crime or whether the effect diminishes with an increase in time spent apart.
In conclusion, this study adds valuable insight into the nature of fear of crime to the literature. Specifically, it provides evidence for the importance of sibling influence on the socialization of fear and vulnerability in women. Important questions that arise from this research include a) how does vicarious fear for siblings contribute to the personal fear of individuals? b) how do women explain the existence of a "big brother effect"? and c) does the "big brother effect" persist over time or does the effect diminish as distance from cohabitation increases? These questions provide avenues for future quantitative and qualitative research into sibling influence and fear of crime.

\section{REFERENCES}

Branje, Susan J.T., Cornelis F.M. van Lieshout, Marcel A. G. van Aken and Gerbert. J. T. Haselager. 2004. "Perceived Support in Sibling Relationships and Adolescent Adjustment." Journal of Child Psychology and Psychiatry 45(8):1385-1396. http://dx.doi.org/10.1111/j.1469-7610.2004.00332.x

Brody, Gene H. 2004. "Siblings' Direct and Indirect Contributions to Child Development." Current Directions in Psychological Science 13(3):124-126.

http://dx.doi.org/10.1111/j.0963-7214.2004.00289.x

Bronstein, Phyllis, Maria Briones, Teri Brooks, and Brookes Cowan. 1996. "Gender and Family Factors as Predictors of Late Adolescent Emotional Expressiveness and Adjustment: A Longitudinal Study." Sex Roles 34: 739-765. http://dx.doi.org/10.1007/BF01544314

Brownlow, Alec. 2005. "A Geography of Men's Fear." Geoforum 36(5):581-592. http://dx.doi.org/10.1016/j.geoforum.2004.11.005

Clement, Frank and Michael B. Kleiman. 1977. "Fear of Crime in the United States: A Multivariate Analysis." Social forces 56(2):519-531.

http://dx.doi.org/10.1093/sf/56.2.519

De Groof, Saskia. 2008. "And My Mama Said: The (Relative) Parental Influence on Fear of Crime Among Adolescent Girls and Boys." Youth Society 39(3):267-293. http://dx.doi.org/10.1177/0044118X07301000

Dowler, Kenneth. 2003. "Media Consumption and Public Attitudes Toward Crime and Justice: The Relationship Between Fear of Crime, Punitive Attitudes, and Perceived Police Effectiveness." Journal of Criminal Justice and Popular Culture 10(2):109-126.

Downey, Douglas B. 2001. "Number of Siblings and Intellectual Development: The Resource Dilution Explanation." American Psychologist 56(6):497-504. http://dx.doi.org/10.1037/0003-066X.56.6-7.497

Ernst, Cecile and Jules Angst. 1983. Birth Order: Its Influence on Personality. Berlin: Springer-Verlag.

Falbo, Toni and Denise F. Polit. 1986. "Quantitative Review of the Only Child Literature: Research Evidence and Theory Development." Psychological Bulletin 100(2):176-189. http://dx.doi.org/10.1037/0033-2909.100.2.176

Ferguson, Kristin M. and Charles H. Mindel. 2007. "Modeling Fear of Crime in Dallas Neighborhoods: A Test of Social Capital Theory." Crime \& Delinquency 53(2):322-349. http://dx.doi.org/10.1177/0011128705285039

Ferraro, Kenneth F. and Randy L. Grange. 2007. "The Measurement of Fear of Crime." Sociological Inquiry 57(1):70-97. http://dx.doi.org/10.1111/j.1475-682X.1987.tb01181.x 
Fitzgerald, Robin. 2008. Fear of crime and the neighbourhood context in Canadian cities. Ottawa: Canadian Centre for Justice Statistics. Retrieved from http://www.statcan.gc.ca/ pub/85-561-m/85-561-m2008013-eng.htm

Garside, Rula B. and Bonnie Klimes-Dougan. 2002. "Socialization of Discrete Negative Emotions: Gender Differences and Links with Psychological Distress." Sex Roles 47:115-128. http://dx.doi.org/10.1023/A:1021090904785

Gass, Krista, Jennifer Jenkins, and Judy Dunn. 2007. "Are Sibling Relationships Protective? A Longitudinal Study." Journal of Child Psychology and Psychiatry 48(2):167-175. http://dx.doi.org/10.1111/j.1469-7610.2006.01699.x

Gray, Emily, Jonathan Jackson, and Stephan Farrall. 2008. "Researching Everyday Emotions: Towards a Multidisciplinary Investigation of the Fear of Crime." Pp. 3-24 in Fear of crime - Punitivity: New Developments in Theory and Research, edited by $\mathrm{H}$. Kury. Bochum, Germany: Universitatsverlag Brockmeyer.

Hollander, Jocelyn A. 2001. "Vulnerability and Dangerousness: The Construction of Gender through Conversation about Violence." Gender and Society 15(1): 83-109.

http://dx.doi.org/10.1177/089124301015001005

IBM Corp. 2011. IBM SPSS Statistics for Windows, Version 20.0. Armonk, NY: IBM Corp.

Jackson, Jonathan. 2006. "Introducing Fear of Crime to Risk Research." Risk Analysis 26(1):253-264. http://dx.doi.org/10.1111/j.1539-6924.2006.00715.x

Jackson, Jonathan. 2009. "A Psychological Perspective on Vulnerability in the Fear of Crime." Psychology, Crime \& Law 15(4):365-390. http://dx.doi.org/10.1080/10683160802275797

Jenkins, Jennifer M. and Marjorie A. Smith. 1990. "Factors Protecting Children Living in Disharmonious Homes: Maternal Reports." Journal of the American Academy of Child \& Adolescent Psychiatry 29(1):60-69. http://dx.doi.org/10.1097/00004583-199001000-00011

Kitzmann, Katherine M., Robert Cohen, and Rebecca L. Lockwood. 2002. "Are Only Children Missing Out? Comparison of the Peer-Related Social Competence of Only Children and Siblings." Journal of Social and Personal Relationships 19(3):299-316.

http://dx.doi.org/10.1177/0265407502193001

Kornreich, Jennifer L., Kimberly D. Hearn, Giovanna Rodriguez, and Lucia F. O'Sullivan. 2003. "Sibling Influence, Gender Roles, and the Sexual Socialization of Urban Early Adolescent Girls." The Journal of Sex Research 40(1):101-110. http://dx.doi.org/10.1080/00224490309552170

May, David C., Nicole E. Rader, and Sarah Goodrum. 2010. "A Gendered Assessment of the "Threat of Victimization": Examining Gender Differences in Fear of Crime, Perceived Risk, Avoidance, and Defensive Behaviours." Criminal Justice Review 35(2):159-182. http://dx.doi.org/10.1177/0734016809349166

May, David C., Lesa Rae Vartanian, and Keri Virgo. 2002. "The Impact of Parental Attachment and Supervision on Fear of Crime Among Adolescent Males." Adolescence 37(146): 267-287.

McCrea, Rod, Tung-Kai Shyy, John Western, and Robert Stimson. 2005. "Fear of Crime in Brisbane: Individual, Social and Neighbourhood Factors in Perspective." Journal of Sociology 41(1):7-27. http://dx.doi.org/10.1177/1440783305048381

Mclntyre, Jennie J. 1967. "Public Attitudes Toward Crime and Law Enforcement." The Annals of the American Academy of Political and Social Science 374:34-36. http://dx.doi.org/10.1177/000271626737400104

McMaster University Office of Institutional Research and Analysis. 2011. McMaster University Fact Book 2010-2011. Retrieved from http://www.mcmaster.ca/avpira/documents/factbook/ FactBook20102011.pdf
Mesch, Gustavo S. 2000. "Women's Fear of Crime: The Role of Fear for the Well-Being of Significant Others." Violence and Victims 15(3):323-336

Miller, Joel. 2008. "Impact of Situational Factors on Survey Measured Fear of Crime." International Journal of Social Research Methodology 11(4):307-325. http://dx.doi.org/10.1080/13645570701606093

Moore, Mark H. and Robert C. Trojanowicz. 1988. "Policing and the Fear of Crime." Pp. 1-7 in Perspectives on Policing, Vol. 3. Washington, DC: U.S. Department of Justice, National Institute of Justice.

Price, Joseph. 2008. "Parent-Child Quality Time: Does Birth Order Matter?" The Journal of Human Resources 43(1):240-265. http://dx.doi.org/10.1353/jhr.2008.0023

Rader, Nicole E. 2010. "Until Death Do Us Part? Husband Perceptions and Responses to Fear of Crime." Deviant Behaviour 31(1):33-59. http://dx.doi.org/10.1080/01639620902854704

Rader, Nicole E. and Stacy H. Haynes. 2011. "Gendered Fear of Crime Socialization: An Extension of Aker's Social Learning Theory." Feminist Criminology 6(4):291-307. http://dx.doi.org/10.1177/1557085111408278

Renauer, Brian C. 2007. "Reducing Fear of Crime: Citizen, Police, or Governmental Responsibility." Police Quarterly 10(41):41-62. http://dx.doi.org/10.1177/1098611106286894

Sandler, Irwin N. 1980. "Social Support Resources, Stress, and Maladjustment of Poor Children." American Journal of Community Psychology 8(1):41-52. http://dx.doi.org/10.1007/BF00892280

Salmi, Satu, Martti Gronroos, and Esko Keskinen. 2004. "The Role of Police Visibility in Fear of Crime in Finland." Policing: An International Journal of Policing Strategies \& Management 27(4):573-591. http://dx.doi.org/10.1108/13639510410566280

Schachter, Stanley. 1963. "Birth Order, Eminence and Higher Education." American Sociological Review 28(5):757-768. http://dx.doi.org/10.2307/2089913

Semmens, Natasha, Jennifer Dillane, and Jason Ditton. 2002 "Preliminary Findings on Seasonality and the Fear of Crime: A Research Note." British Journal of Criminology 42(4):798806. http://dx.doi.org/10.1093/bjc/42.4.798

Snedker, Karen A. 2006. "Altruistic and Vicarious Fear of Crime: Fear For Others and Gendered Social Roles." Sociological Forum 21(2):163-195. http://dx.doi.org/10.1007/s11206-006-9019-1

Steelman, Lala C. 1985. "A Tale of Two Variables: A Review of the Intellectual Consequences of Sibship size and Birth Order." Review of Educational Research 55(3):353-386. http://dx.doi.org/10.3102/00346543055003353

Stoneman, Zolinda and Gene H. Brody. 1986. "Same-Sex and Cross-Sex Siblings: Activity Choices, Roles, Behaviour, and Gender Stereotypes." Sex Roles 15:495-511. http://dx.doi.org/10.1007/BF00288227

Sulloway, Frank J. 1996. Born to Rebel: Birth Order, Family Dynamics, and Creative Lives. New York: Vintage Books.

Sutton, Robbie M. and Stephen Farrall. 2005. "Gender, Socially Desirable Responding and the Fear of Crime: Are Women Really More Anxious about Crime?" British Journal of Criminology 45: 212-224. http://dx.doi.org/10.1093/bjc/azh084

Sutton-Smith, Brian and Benjamin G. Rosenberg. 1970. The Sibling. New York: Hold, Rinehard, \& Winston

Thomas, Charles W. and Samuel C. Foster. 1975. "A Sociological Perspective on Public Support for Capital Punishment." American Journal of Orthopsychiatry 45(4):641-657. http://dx.doi.org/10.1111/j.1939-0025.1975.tb01192.x 
Vaillancourt, Roxan. 2010. Gender Differences in Police-reported Violent Crime in Canada, 2008. Statistics Canada Catalogue no. 85F0033MWE. Ottawa. Canadian Centre for Justice Statistics Profile Series, no. 24. Retrieved from http://www.statcan.gc.ca/pub/85f0033m/2010024/partpartie1-eng.htm

Volkom, Michael V. 2003. "The Relationships Between Childhood Tomboyism, Siblings' Activities, and Adult Gender Roles." Sex Roles 41(11):609-618. http://dx.doi.org/10.1023/B:SERS.0000003131.98867.a1
Warr, Mark. 1992. "Altruistic Fear of Victimization in Households." Social Science Quarterly 73(4): 723-736.

Warr, Mark and Christopher G. Ellison. 2000. "Rethinking Social Reactions to Crime: Personal and Altruistic Fear in Family Households." AJS 106(3):551-578.

Warr, Mark. 2000. "Fear of Crime in the United States: Avenues for Research and Policy." Pp. 451-489 in Criminal Justice 2000, Vol. 4: Measurement and Analysis of Crime and Justice, edited by D. Duffee. Washington, DC: U.S. Department of Justice. National Institute of Justice.

Received on 21-11-2013 Accepted on 23-04-2014

Published on 23-05-2014

DOI: http://dx.doi.org/10.6000/1929-4409.2014.03.13

(C) 2014 Jessica Ashbourne; Licensee Lifescience Global.

This is an open access article licensed under the terms of the Creative Commons Attribution Non-Commercial License (http://creativecommons.org/licenses/by-nc/3.0/) which permits unrestricted, non-commercial use, distribution and reproduction in any medium, provided the work is properly cited. 